\title{
ČEŠTÍ DISIDENTI A JEJICH SVĚTOVÝ OHLAS
} Ohlédnutí za Rogerem Scrutonem (1944-2020)

Českých intelektuálních tradic, které by měly skutečně celosvětový ohlas, není mnoho. Promýšlení fenoménu disentu k nim však jednoznačně patří. Témata typická pro české filosofické prostředí se stala součástí globálního porozumění totalitním režimům, jejich charakteru a dopadům na život společnosti. Rovněž formovala představy o tom, co znamená těmto režimům čelit. K těmto tématům patří vztah k pravdě jako klíčové politické kategorii, analýza (ne)autenticity našeho jednání v pokřivených politických podmínkách či schopnost jednotlivce dostat moc pod tlak jednoduchým trváním na tom, aby režim dodržoval svá vlastní pravidla. V běloruské „Chartě 97 “, čínské „Chartě $08^{\prime \prime}$ a v mnohých dalších disidentských hnutích tak čteme jasný rukopis zdejšího vypořádání se s totalitou.

Proč však právě český disent získal takový vliv? Přesná historická rekonstrukce samozřejmě překračuje meze tohoto textu. V rámci jistého zjednodušení proto uvedu pouze dva klíčové prvky. Prvním z nich je filosofický charakter zdejší opozice. V ostrém kontrastu například s Polskem, kde byli tváří odporu vůči komunistickému režimu dělníci v loděnicích, ale i se Slovenskem, kde disentu dominovali věřící a ekologičtí aktivisté, byli v Česku nejviditelnějšími oponenty režimu právě filosofové. To mělo zásadní vliv na charakter celého hnutí. Nešlo ,jen“ o boj za lepší pracovní podmínky, svobodu vyznání či ochranu přírody. Podstatné bylo také reflektovat zkušenost odporu vůči politické moci, analyzovat totalitní režimy a jejich vnitřní rozpory spolu s jejich dopady na občanskou společnost. Vznikla zde tedy intelektuální tradice, z níž bylo možné dále čerpat.

Tato intelektuální tradice, a to je druhý kousek skládačky, následně prorazila do povědomí intelektuálů na Západě. Přispěl k tomu věhlas Václava Havla, ale také „drobná práce“ mnohých sympatizantů a podporovatelů českého disentu sdružených okolo Nadace Jana Husa. Jednou z jejích nejvýznamnějších tváří byl i nedávno zesnulý Roger Scruton. 
Scruton opakovaně jezdil do Československa, zprostředkoval pro některé české disidenty distanční studium na universitě v Cambridgi, a dokonce se po revoluci na čas přestěhoval do Brna. Jak dosvědčuje výše přeložený úryvek z jeho Slovníku politického myšlení, česká intelektuální tradice mu byla mimořádně blízká. Ve své práci, přednáškách a publikacích ji následně zprostředkovával širokému okruhu svých čtenářů. Jeho úmrtím česká filosofie ztratila člověka, jenž jí (doslova) rozuměl.

Matej Cíbik 